\title{
KINO POWOJENNE I PUŁAPKI NASZEJ ŚWIADOMOŚCI
}

TADEUSZ SOBOLEWSKI

tadeusz.sobolewski@agora.pl

Swój artykuł traktuję jako wypowiedź nie tyle o samej historii - tej najnowszej i tej tzw. peerelowskiej, powojennej - ile o naszej świadomości: świadomości ludzi wychowanych w PRL-u. W moim przypadku, jednym z kluczowych elementów tej świadomości, miejscem jej skupienia, obok tradycji rodzinnej, było kino. Przywołam dwa filmy, zrealizowane w odstępie 50 lat, a dotyczące kompleksu świadomości zbiorowej. Zestawienie może się wydać zaskakujące: Popiół $i$ diament Andrzeja Wajdy i Wszyscy jesteśmy Chrystusami Marka Koterskiego.

Kompleks, o który chodzi, ma swoje źródło w poczuciu klęski zawinionej przez obcych. Uraz ten jest zrozumiały, ale jak każdą chorobę, trzeba go leczyć, bo inaczej zatruje do reszty naszą sferę publiczną, naszą wyobraźnię i naszą politykę. Myślę tu o patriotyzmie żałobnym. O kulcie klęski i przywiązaniu do niej, o perwersyjnym jej przywoływaniu.

Myślę o polskim mesjanizmie, głęboko zakorzenionym, jeśli nie w czasach baroku, to na pewno w romantyzmie. Wydawało się, że kolejne pokolenia, działające w roku '56, '68, '76, '80, '89, pracujące skutecznie na rzecz wolności, osłabiły ten kompleks. Okazało się jednak, że wybucha on z nową siłą.

Zacytuję dwa teksty, reprezentujące różne style - wysoki i niski. Pierwszy to fragment romantycznej biblii Polaków, drugi - spontaniczna wypowiedź aktywisty spod krzyża na Krakowskim Przedmieściu, zanotowana w etiudzie 
studenta łódzkiej szkoły filmowej, Michała Brożonowicza, zatytułowanej Mam prawo tu stać.

Oto kluczowe zdania z Ksiag Narodu i Pielgrzymstwa Adama Mickiewicza:

I umęczono naród polski i złożono w grobie, a królowie wykrzyknęli: zabiliśmy i pochowaliśmy Wolność. [...] [N]aród polski nie umarł [...], A trzeciego dnia dusza wróci do ciała, i naród zmartwychwstanie i uwolni wszystkie ludy Europy z niewoli ${ }^{1}$.

Opisana tu wizja męczeństwa narodu, skojarzonego z męczeństwem Chrystusa, niosącym wolność całemu światu, od dwustu lat ciąży na polskiej świadomości. Dwudziestowieczni krytycy tej tradycji - Czesław Miłosz, Maria Janion - obwiniali ją o sprzyjanie narodowemu bałwochwalstwu, tworzenie perwersyjnej megalomanii cierpienia, kultu śmiertelnej ofiary. Dodajmy: oznacza to widzenie naszej zbiorowej sytuacji zawsze w gorszym świetle niż jest. Zgodnie z tą tradycją Polska powojenna jest ukazana wyłącznie w męczeńsko-heroicznym świetle, tak jakby społeczeństwo składało się tylko z prześladowców i prześladowanych.

Oto autentyczny głos z warszawskiej ulicy z roku 2010: „Naród polski zablokuje wejście do pałacu, a tego zdrajcy, pachołka Rosji w ogóle nie wpuszczać!" - tak wołał obrońca krzyża do milczącego mężczyzny i do stojącej tam kamery. Fragment przypomina modelowy tekst, który możemy dziś usłyszeć od polityków, a jego ludową wersję reprezentuje poniższa wypowiedź

- Teraz rozleje się krew! Teraz naród, który jest podzielony, rozleje krew! Nie będziemy tolerować morderców, którzy nie mogą wyjaśnić katastrofy smoleńskiej! Nie jesteś Polakiem, bo oddałeś głos na zdrajcę narodu! Będzie się lała polska krew. Ja jestem gotów oddać swoje życie, za

${ }^{1}$ A. Mickiewicz, Księgi narodu polskiego. Od poczatku świata aż do umęczenia narodu polskiego, [w:] Księgi narodu polskiego i pielgrzymstwa polskiego, Paryż 1832, s. 23, tekst dostępny na stronie: https://pl.wikisource.org/wiki/Księgi_narodu_polskiego [data dostępu: 5.11.15]. 
prezydenta, pośmiertnie, tego, który został zamordowany. Ja jako Polak. A ty kto jesteś? Jeśli nie jesteś Polakiem, nie ma tu twojego miejsca! ${ }^{2}$

Oto uliczna karykatura romantycznego mesjanizmu, funkcjonująca w Polsce w roku 2010. Chciałbym natomiast przypomnieć rok niezwykle ważny w powojennej historii Polski. Ważny dla mnie dlatego, że był pierwszym momentem, kiedy zaczęła się krystalizować moja, wtedy jeszcze dziecięca, świadomość narodowa. Rok 1956. W tym samym czasie, gdy Armia Radziecka miażdżyła Budapeszt, w Polsce udała się samoograniczająca się rewolucja, podobna do późniejszej Praskiej Wiosny czy ruchu „Solidarności”. W fabrykach powoływano do istnienia samorządy robotnicze, zelżała cenzura, życie publiczne wymknęło się spod kontroli władzy, zaczęły powstawać różnego rodzaju stowarzyszenia, kluby. W tej atmosferze tworzono popaździernikową sztukę. Tylko wtedy mogły powstać: Kanat, Eroica czy Popiót i diament. (Tak jak w połowie lat 70. zaistniała atmosfera, w której mógł powstać Człowiek z marmuru, 12 lat czekający na realizację.)

Nurt wolnościowych przemian został zatrzymany wkrótce po '56. roku. Gomułka w obawie przed Rosją ,przykręcił śrubę”. Procesu emancypacji nie dało się jednak cofnąć, można go było tylko powstrzymywać, czasem krwawo. Z dzisiejszej perspektywy widać wyraźnie, że konwulsje społeczne kolejnych dekad to były przęsła jednego mostu, który prowadził do demokracji. Nie żyliśmy w świecie Orwella - ideologia komunistyczna była kamuflażem, a dyktatura dziurawa. Wolności z czasem przybywało, nie ubywało. Czas, który minął - czas młodości mojego pokolenia, które weszło w życie w latach 70., nie był czasem straconym.

Polska Ludowa (tak zwany PRL) składała się z wielu enklaw. Jedną z nich było kino. Szkoła polska. Uczyłem się na filmach tej szkoły - Kanał i Popiót

${ }^{2}$ Tekst zasłyszany na ulicach Krakowskiego Przedmieścia w Warszawie w maju 2010 roku. 
i diament Wajdy czy Eroica Munka. Dzieła te proponowały zuchwały stosunek do historii.

Mam wrażenie, że tamte postacie, jak np. Maciek Chełmicki, główny bohater Popiołu i diamentu, są wychylone w przyszłość. To wychylenie, ten dynamizm, nadzieja na zmianę były fascynującą cechą kultury lat 50., 60. i 70.

Munk, Wajda, Has, Kawalerowicz, Konwicki - ówczesne kino robili ludzie, na których oczach kilkakrotnie zawalił się świat. Byli w wieku szkolnym, kiedy wybuchła II wojna światowa, a młode państwo polskie rozpadło się jak domek z kart. Potem widzieli klęskę Powstania Warszawskiego 1944 roku. W 1945 przyszło wyzwolenie, które miało cechy nowej niewoli; ustrój, który obiecywał pokój i sprawiedliwość społeczną, krył zbrodnie.

Ciekawe, że kiedy terror zelżał, młoda inteligencja zareagowała w sposób paradoksalny, nowoczesny. Zerwała z panującym kultem historii, wymagającej zbyt wielkich ofiar. W 1956 roku w Warszawie, w domowym Teatrze na Tarczyńskiej Miron Białoszewski wystawiał groteskę o wyprawach krzyżowych. Spektakl kończył się parodią hasła Majakowskiego o tym, że trzeba „Zajeździć kobyłę historii”. Nieprawda - odpowiadał poeta - „kobyłę historii” trzeba „rozkulbaczyć”, zsiąść z niej. W warszawskim STS śpiewano zaś takie kuplety o ojczyźnie:
Znalazłem wreszcie i na ciebie sposób, już więcej nad tym głowić się nie muszę: bądź dla mnie zawsze paczką papierosów, biletem trzeciej klasy do Koluszek. Bądź pumperniklem, bądź polopiryną, ale już nigdy więcej nie bądź blizną - nasza kochana, bezcenna ojczyzno! ${ }^{3}$

${ }^{3}$ A. Osiecka, Inwokacja, tekst dostępny na stronie www.poezja-spiewana.pl/index.php?str=lf\&no=10581 [data dostępu: 5.11.15]. 
Historia objawiła się artystom tego pokolenia jako groźne bóstwo żądające ofiar. Po doświadczeniu hitleryzmu i stalinizmu nie chciano już więcej oddawać hołdu temu bóstwu. Ostrze krytyki było skierowane z jednej strony przeciw komunizmowi, wzywającemu do poświęceń w imię świetlanej przyszłości, ale z drugiej strony rewidowano też tradycję romantyczną - ona również miała w sobie zalążek totalitaryzmu.

Popiót i diament mówi właśnie o bezsensownej śmierci i daremnej ofierze. „Ja już nie mogę zabijać, ukrywać się, ja chcę żyć, ja muszę żyć..." - powtarza Maciek. Nie ma sensu oczekiwać od tego filmu rzetelnego historycznego wykładu o sytuacji podziemia, wyłapywanego przez polskie i radzieckie służby bezpieczeństwa. W 1958 roku nie było to możliwe. Ale na tajnych pokazach w Rosji, Czechosłowacji czy na Węgrzech podziwiano ten film za co innego: za pokazanie chłopaka z podziemia, z góry skazanego na śmierć, jako kogoś, z kim widz od początku do końca sympatyzuje, który niezależnie od tego, co zrobi, jest po prostu „nasz”, podczas gdy tym „obcym” okazuje się komunista. Inna rzecz, że gdyby wątek komunisty został rozwinięty, okazałby się równie tragiczny i jeszcze bardziej niecenzuralny niż wątek Maćka.

Jego śmierć na śmietniku jest absurdalna, odarta z wzniosłości. Jednak tragedia Maćka oddziaływała jak pochwała życia. Ówcześni widzowie chcieli wierzyć, że historia może ułożyć się tak, żeby nie trzeba było składać daniny krwi. To kino leczyło z poczucia przegranej.

Film Wajdy podobał się młodym ludziom nie dlatego, że był antykomunistyczny. Zastrzelenie komunisty padającego w ramiona Maćka, który wcześniej do niego mierzył; na niebie race zwycięstwa, potem Maciek ze wstrętem odrzucający pistolet - to wszystko niosło zapowiedź końca walki. To właśnie było poruszające i to porusza do dziś: chęć wyjścia poza historię.

Drugi przejmujący obraz to scena $\mathrm{z}$ wiszącym głową w dół krucyfiksem w zrujnowanej kaplicy. Maciek wchodzi tam przypadkiem z poznaną barmanką Krysią. Odwrócony krzyż kojarzy się z nieuniknioną ofiarą, która 
nie ma sensu, idzie na marne. Para zakochanych rozmawia o tym, jakie życie mogłoby być piękne. Bohaterów widzimy zza wiszącego krzyża, ale nie zwracają na niego uwagi, tak jak nie zwracają uwagi na powagę kaplicy, gdy Maciek reperuje na ołtarzu złamany obcas.

Ówczesne kino pracowało na to, by Polska nie była Chrystusem Narodów. Dla pokolenia '56 nadzieją była demokracja, sprawiedliwość społeczna, którą wtedy jeszcze wiązano z socjalizmem lub z czymś w rodzaju „trzeciej drogi” - nie komunistycznej i nie kapitalistycznej. Ta idea po latach powróciła w „Solidarności”.

„Solidarności” również towarzyszył krzyż. Ale nabierał on nowego znaczenia. Nie przedstawiał narodu rozpiętego na krzyżu, był znakiem zwycięstwa. Oba „solidarnościowe” filmy Wajdy, Człowiek z marmuru i Człowiek $z$ żelaza, podejmują wątek mesjanistyczny w nowy sposób, oczyszczony z perwersyjnego kultu cierpienia.

Pożegnaniem romantycznego mesjanizmu w kinie polskim była Lawa Tadeusza Konwickiego z 1989 roku. Konwicki pozwolił sobie na zuchwałość: zakończył misterium happy endem. Stary Konrad deklamuje jeszcze wstęp Mickiewicza do Dziadów: „Czymże są wszystkie ówczesne okrucieństwa w porównaniu z tym, co naród polski teraz cierpi i na co Europa teraz obojętnie patrzy...!"4. Obraz jednak mówi co innego: ten naród już nie cierpi.

Ludzka lawa sunie w gigantycznym pochodzie pierwszomajowym i wylewa się przed Pałacem Kultury, gdzie zamiast trybuny z komunistycznymi przywódcami stoi ołtarz i odprawiana jest msza papieska. Oto krótka historia PRL-u, od komunizmu do „Solidarności”. Bo „Solidarność” też należy do historii Polski Ludowej. Po skończonym dramacie widzimy bramę wytwórni filmowej i ekipę Lawy, reżysera, aktorów. Przed chwilą byli uczestnikami narodowego obrzędu, teraz są zwykłymi przechodniami. Oto koniec

${ }^{4}$ A. Mickiewicz, Dziady, czesść III. Przedmowa, [w:] Dziady, Warszawa 1998, s. 110 . 
narodowego kompleksu. W 1989 roku nie byliśmy ogarnięci romantyczną gorączką. Nie było rewolucji. Na szczęście! Coś przygodnego, normalnego, świeckiego stało się z nami i z krajem. Można było wtedy pomyśleć, że Chrystus będzie już odtąd nie tyle pośrednikiem między człowiekiem a narodem, ile między ludźmi po prostu - w ich wzajemnych stosunkach.

Polski Chrystus wraca w filmie Koterskiego. Wciela się w niego polski everyman - Adaś Miauczyński.

Koterski już w poprzednich filmach, od Domu wariatów po Dzień świra, stworzył parodię polskiego bohatera tragicznego. Adaś chce oduczyć się palenia, ale odkłada to na następny dzień; chce zrobić półki, ale ucina deskę o centymetr za krótko; chce podyskutować z żoną, ale wszystko, co ona powie, wydaje mu się głupie; chce się z nią kochać, ale ona jest zimna. Może naprawdę żona jest okropna, blok brzydki, zsyp hałasuje, a w windach grasuje wampir? Jednak prawdziwym wampirem jest sam Miauczyński, który nie umie „kochać bliźniego jak siebie samego”, bo siebie również ma za nic. Jego agresja wynika z poczucia poniżenia.

Koterskiemu udało się pokazać, jak religijność jest wprzęgnięta w powszednią paranoję. Tak, wszyscy jesteśmy Chrystusami, bo jedni drugich krzyżujemy i każdy przed każdym gra rolę ofiary. Miauczyński, rujnując życie swojej żonie i synowi, dosłownie posyła ich na krzyż, przebija włócznią. A równocześnie sam jest przebijany, upada pod krzyżem, jest ocierany chustą, obnażany z szat w izbie wytrzeźwień.

Trudno o bardziej dosadne przedstawienie, że historia święta, o której opowiada religia i sztuka (Miauczyński jest kulturoznawcą), dzieje się zarazem wewnątrz nas, w mieszkaniach z meblościanką. Nóż z Ostatniej Wieczerzy Leonarda jest tym samym kuchennym nożem, którym żona grozi pijanemu Adasiowi, i którym Adaś w furii masakruje choinkę.

Metafory języka udosłowniają się w obrazie. Mąż i żona dosłownie warczą na siebie jak pies i kot. Ruina naszego życia, której sami jesteśmy winni, przybiera formę gigantycznego śmietniska, gdzie w swoim wyobrażeniu 
ginie Miauczyński - jak Maciek Chełmicki z Popiołu i diamentu. Nie jest on jednak miażdżony przez historię jak tamten bohater - ginie na własną odpowiedzialność.

Koterski może mieć satysfakcję: wyprzedził i zinterpretował krzyżową wojnę Polaków 2010. Adaś Miauczyński prowadzi z Chrystusem nieustanny wewnętrzny dialog, raz utożsamiając się z Nim, to znów targując: pomóż! Jest jak Polska. Pozwala sobie, niby w Jego imieniu, na wypicie ćwiartki wódki w nagrodę. Krzyż jest dla niego rodzajem wytrycha, usprawiedliwieniem własnej słabości, żałosnym wołaniem o litość. Czy Koterski, ukazując życie Miauczyńskiego jako Pasję, nie obnaża w okrutny sposób kiczu naszej świadomości? Ale reżyser daje nam w tym filmie szansę wyjścia poza paranoję. Wprowadza figurę, której nie powstydziłby się sam Luis Buñuel: jeden Chrystus pomaga nieść krzyż drugiemu Chrystusowi. Jeden człowiek - drugiemu. Zgodnie z sentencją Alberta Camusa, z której wzięty jest tytuł tego niedocenionego filmu: „A zatem, skoro wszyscy jesteśmy sędziami, wszyscy jesteśmy winni, jedni wobec drugich, wszyscy jesteśmy Chrystusami na nasz obrzydliwy sposób..."

${ }^{5}$ A. Camus, Upadek, tłum. J. Guze, Kraków 1972. 


\section{Bibliografia}

Albert Camus, Upadek, thum. J. Guze, Wydawnictwo Literackie,

Kraków 1972.

Adam Mickiewicz, Dziady, Spółka Wydawniczo-Księgarska, Warszawa 1998.

Mickiewicz Adam, Księgi narodu polskiego i pielgrzymstwa polskiego, Drukarnia A. Pinard, Paryż 1832, tekst dostępny na stronie https://pl.wikisource.org/wiki/Księgi_narodu_polskiego [data dostępu: 5.11.15].

Agnieszka Osiecka, Inwokacja, tekst dostępny na stronie https://www.poezja-spiewana.pl/index.php?str=lf\&no=10581 [data dostępu: 5.11.15]. 


\section{Postwar Cinema and Traps of Our Consciousness}

The article is a reflection on postwar Polish cinema as a representation of Polish mentality. The analysis is based on the following films: Andrzej Wajda's Popiót i diament (Ashes and Diamonds) and Marek Koterski's Wszyscy jesteśmy Chrystusami (We're All Christs) whose juxtaposition allows to visualize a complex characteristic for Polish consciousness - mournful patriotism, which is associated with messianism. Artistic artifacts are treated as a complementary element that comment on the social reality of specific historical moments.

Keywords: messianism, Popiót i diament (Ashes and Diamonds), Wszyscy jesteśmy Chrystusami (We're All Christs), mournful patriotism, postwar cinema, Polishness. 


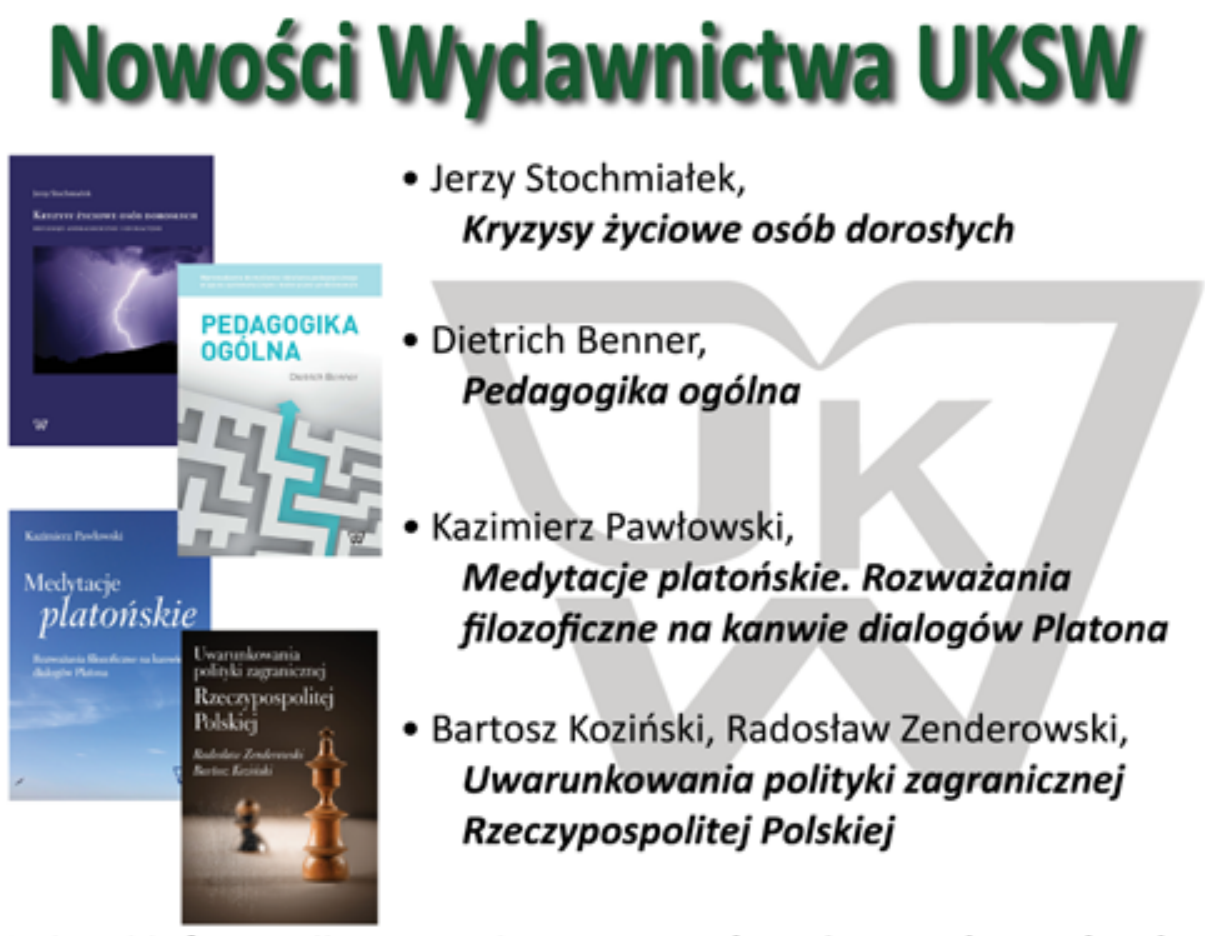

Więcej informacji na stronie: www.wydawnictwo.uksw.edu.pl 